\title{
Impact of epidemic infectious disease and death on stock returns: Evidences from Asian stock markets with COVID-19
}

\author{
Shiba Prasad Sapkota
}

\begin{abstract}
The causal comparative study regarding impact of pandemic COVID-19 on stock return revealed that the changes on daily confirmed new cases have been severely inflected stock returns in overall as well as cross-over the industries. Whereas, the influence of death form COVID-19 found negative but mostly insignificant. The categorical variables size of economy, geographical area, regulations, and countryspecific impact have been found very low. The empirical evidences were examined using causality test with the backing of regression. The study period has covered $20^{\text {th }}$ January to $30^{\text {th }}$ May 2020, considering eight nations: China, India, Israel, Japan, Korea Republic, Malaysia, Saudi Arabia, and United Arab Emirates, as samples.
\end{abstract}

Key words: Asian stock market; Causality relationship; COVID-19; Stock return

\section{Introduction}

The long run stock returns follow a specific path of movement. As the over-reactions stimulate in the other side of the coin under-reactions limit its boundaries. Similarly, post-event reactions normalize pre-event reactions and vice-versa. Hence, market efficiency hypothesis is inhibitable (Fama, 1998). However, it turns fragile in short period of time and tends to be disappeared. The public information is equally available to all, but private information is by nature private in short period and stock markets tends to be semi-strong form. In case of semi-strong form, market cannot be efficient (Malkiel, 2003). As the stock markets do exist with collective judgment of

\footnotetext{
${ }^{1}$ Cite this article as: Sapkota, S.P. (2020). Contemporary Research: An Interdisciplinary Academic Journal, vol. 4 (1)

Shiba Prasad Sapkota, Associate Professor, Kailali Multiple Campus, Nepal.

Email: sheshank1981@gmail.com

Article history: Received on July 21; Accepted on October 21; Published on October 30

Peer reviewed under the authority of CRAIAJ, academic journal of Ghodaghodi Multiple Campus, Kailali, Nepal, with ISSN 2717-4611 (Print) and ISSN 2717-462X (Online).

(C) 2020 CRAIAJ
}

Full text of this article can be downloaded from www.craiaj.com and www.nepjol.info 
investors and ruled by expectations this argument has been supported by the study Mallikarjunappa (2004). Similarly, Mallikarjunappa \& Dsouza (2013) come up with consistent findings from the evidence of Indian stock markets.

Economic uncertainty increases the market volatility (Bowes, 2018). Whereas, the efficient market hypothesis presumed that stock market immediately reflects relative response of any information. But some circumstances create uncertainty in the economy the breakthrough on regulatory and fiscal policies and price of the stock would be more volatile. Hence, the diversification in the expectations of investors might make more volatile stock market, for instance, world economic crisis, economic effect of pandemic infectious disease, war, and other world class circumstances. This study has focused on impact of COVID-19 in the Asian stock markets.

In Wuhan City, Hubei Province of China a case of pneumonia of unknown etiology was detected on $31^{\text {st }}$ December 2019. Chinese authority identified a new type of Corona virus on $7^{\text {th }}$ January 2020 (WHO $1^{\text {st }}$ Situational Report, $21^{\text {st }}$ January 2020: https://www.who.int/docs/default-source/coronaviruse/situation-reports/20200121sitrep-1-2019-ncov.pdf?sfvrsn=20a99c10_4). Then this infectious disease spread over the whole world and today ( $12^{\text {th }}$ June 2020$)$ at the time of writing this report more than 7.67 million cases have been detected. Out of them four hundred twenty-five thousand nine hundred nineteen have died due to this disease and more than 3.88 million have recovered. Still it has not declared the exact way out from this pandemic. Some of the pharmaceutical companies have been engaged in the process of developing antivirus medicine. However, till today the world has not been able to entirely cure this disease. So, it is not clear that how long this pandemic will continue and to what extent economy of the world will be affected. Among the pillars of economy stock market is an important. How this pandemic has influenced stock market is the prime concern of this paper.

Researches on the Impact of COVID-19 on stock market of United States have been conducted (Onali, 2020). The study includes the infectious cases and deaths of United States, China, Italy, Spain, the UK, Iran and France for the period of first three months up to $9^{\text {th }}$ April 2020. The paper argued that in the first three months COVID-19 crisis majorly affected human beings but did not have impact on stock 
market. Number of studies analyzed the short-term impact of the COVID-19 pandemic on 21 leading stock markets in major affected countries including Japan, Korea Republic, Singapore, United States, Germany, Italy and United Kingdom etc (Liu, Manzoor, wang, Zhang, \& Manzoor , 2020). The paper used event study as well as panel data analysis and verified the results that COVID-19 outbreak adversely impacted on the stock market. Further, the Asian stock markets have been influenced more than others. Studies have investigated the impact of the disease on stock market of China using panel data analysis and argued that daily growth in total conformed cases and death caused by COVID-19 have significantly negative effect on stock returns across the companies (Al-Awadhi, Alsaifi, Al-Awadhi \& Alhammadi, 2020). Sansa (2020) has also analyzed the impact of COVID-19 on stock markets of China and United States during the period of 1-25 March 2020 using time series data. The paper argued that there has been positive and significant relationship between COVID-19 confirmed cases and stock return.

The evidences show that diversified results that some of the stock markets have been severely influenced, some less influenced, somewhere, significant and negative relationship, somewhere significant and positive relationship. Hence, a genuine issue has been raised in the context of Asia, to what extent COVID-19 has impacted on stock return. Further, which industry has been influenced more, could be investigating issue. Similarly, the categorical variables, size of stock markets, regulation, and geography have impact on stock return in the period of pandemic. This paper has attempted to fill that void.

Regarding the relationship between stock return and size Benz (1981) stated that small firms have significantly larger risk adjusted returns than large firms. In this regard, scholars have argued that size significantly holds explaining power to stock return (Chang \& Chang, Hamao \& Lakonishok, 1991). Studies have also stated that the size has negative relationship with stock return in North America, Europe and Pacific Asia but Japan has positive relationship (Fama \& French, 2011). Keim (2018) stated strong negative relationship between stock return and size. From these evidences a presumed hypothesis has been developed - the small sized stock markets earned at higher rate and at the same time the losing rate is also higher. Does this hypothesis function true along with pandemic COVID-19 effect? Economic uncertainty increases the stock market volatility (Bowes, 2018). The circumstances or 
events that create uncertainty in any part of the world become volatile in the stock markets of whole world. The pandemic disease has influenced different countries differently. Some of the nations have been affected earlier, while some nations got affected thereafter. Further the impact of COVID-19 has been seen worldwide. In this regard the priori hypothesis is that the impact of the pandemic should be worldwide. Is this hypothesis true, or different nations and different part of the world have been affected differently? The third hypothesis is government regulated stock market perform well rather than autonomous BOD regulated stock markets because the government regulated stock markets are more controlled and not overwhelmed than autonomous BOD regulated. Here the regulation not only implies controlling but also taking responsibility. The government should take care of national economy in the condition of crisis, but more responsibility goes to operated and controlled organizations by the government. So, in these days a question regarding the existence of free market economy and role of government has been raised by the economists. $\mathrm{He}$ argued that in the countries where there is centralized government system, the pandemic disease has been easily controlled, for example, in china. If the effect of pandemic extends for a long period of time, the role of government will be inevitable in the primary sectors like health and education. Similarly, the role of government will be increased, and the stock market cannot be the exception. If the role of government increases the efficiency of stock market will decrease. In the context of normal situation, the stock market regulated by autonomous BOD may perform well but in the situation of crisis the government regulated stock markets could be safer. So, the government regulated stock markets or autonomous BOD regulated sock markets, which one has performed well, could be interesting investing issue in the period of pandemic.

The study has not strictly been guided by the deductive approach. In the case of deductive approach, theoretical framework can be developed. But this study has modified concept as per the need of study. So, the conceptual framework has been developed. In the above figure the changes on new cases of COVID-19 and death have been considered as independent variables. Stock return has been considered as dependent variable with classified into different industries. The size of stock markets in terms of market capitalization, regulation, and geography has been considered as categorical variables. While considering the variables, changes on new cases of COVID-19 and deaths have been occurred daily, whereas the stock price was 
available of operating days only. Hence, this study has made an assumption that the investors do reflect the reactions based on the available information of previous day. So, if the stock market has closed in the holidays the information of last day has been considered for that day.

Figure 1: Conceptual framework

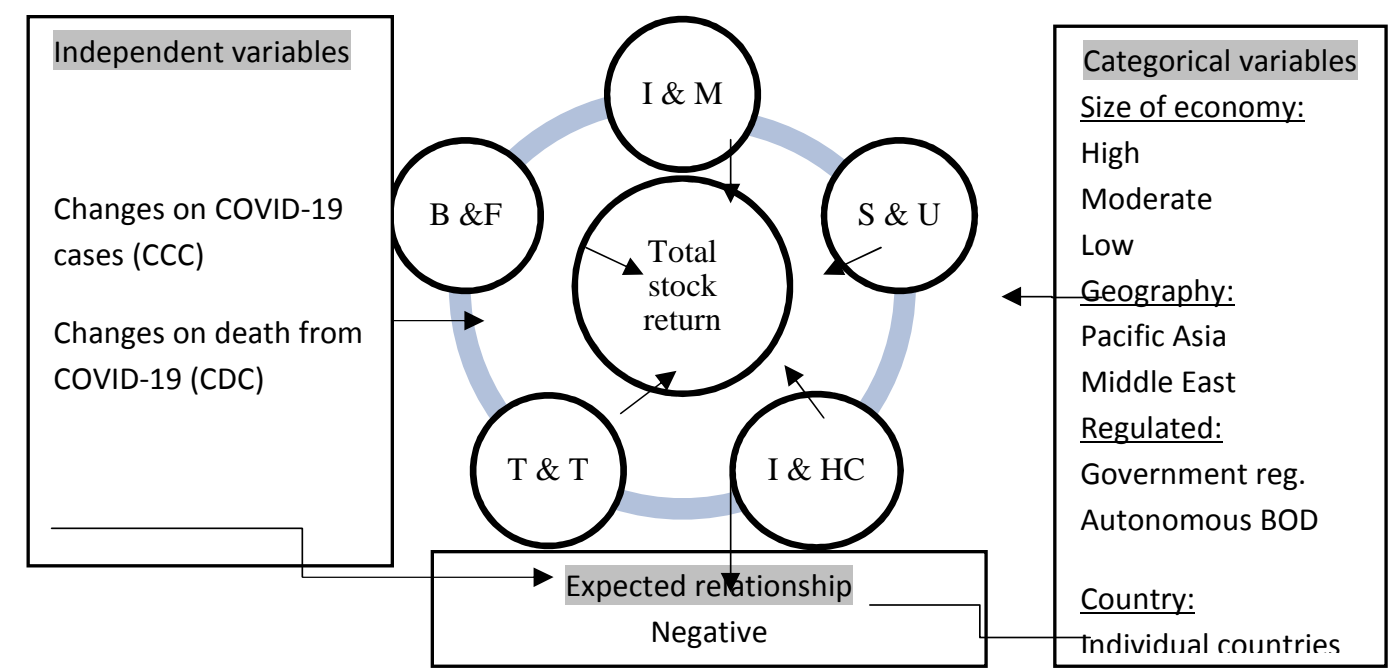

Where, $B \& F$ - banking and finance, $I \& M-$ industry and manufacturing, $S \& U-$ services and utility, $I \& H C$ - insurance and health care, $T \& T$ - Transport and Tourism, BOD - board of directors.

\section{Methodology}

Asia continent has significant position in terms of economic activities, population, and geography in the world. Further the COVID-19 has spread from this continent. Hence the impact of this virus in this continent could be remarkable. The infectious cases from the pandemic was more than 1.59 million and total deaths from this disease was thirty-nine thousand six hundred eighty on June 14, 2020, whereas the population of this region was around sixty percent of the total population of world (worldometers: https://www.worldometers.info/world-population/). This continent has 51 countries among them eight countries have been chosen for the study. While selecting the sample the following criteria have been developed: first, the nation should have operated stock markets in the period of the pandemic (January 1, 2020 to May 31, 2020) and information should have available in 
(https://www.investing.com). Second, the stock markets should have developed different clusters at least banking or finance, insurance or health care, industry or manufacturing, transport or tourism and services or utilities. Considering these yardstick principles, China, India, Israel, Japan, Malaysia, Korea Republic, Saudi Arabia, and United Arabs Emirates have been chosen for the study. Then if a country has two or more stock markets then the stock market which has larger number of investors have been chosen for the study. The impact of infectious cases and death from COVID-19 on stock return has been examined in five major categories of listings of the stock market. Then after these stock markets have been categorized into three clusters: high, moderate, and low based on market capitalization to control the impact of size. Similarly, the geographical area - Asia Pacific and Middle East - and regulation of the stock market - government regulated and autonomous BOD regulated - has been divided to examine the impact size, geography, and regulation along with COVID-19. The sample countries and their stock markets have been presented below:

Table1: Sample countries and their stock markets with industry clusters

\begin{tabular}{|c|c|c|c|c|c|c|c|c|c|}
\hline \multirow{2}{*}{\begin{tabular}{|l|}
$\mathrm{S}$ \\
$\mathrm{N}$
\end{tabular}} & \multirow[t]{2}{*}{ Countries } & \multirow{2}{*}{$\begin{array}{l}\text { Stock } \\
\text { Markets }\end{array}$} & \multicolumn{2}{|l|}{ Index price } & \multicolumn{5}{|c|}{ Clusters } \\
\hline & & & $20 / 01 / 2020$ & $29 / 05 / 2020$ & B \&F & I\&M & S\&U & $\mathrm{I} \& \mathrm{HC}$ & H\&T \\
\hline 1 & China & SSE & $3,095.79$ & $2,852.35$ & $\sqrt{ }$ & $\sqrt{ }$ & $\sqrt{ }$ & $\sqrt{ }$ & $\sqrt{ }$ \\
\hline 2 & India & BSE & $41,528.91$ & $32,424.10$ & $\sqrt{ }$ & $\sqrt{ }$ & $\sqrt{ }$ & $\sqrt{ }$ & $\mathrm{X}$ \\
\hline 3 & Israel & TA & $1,724.00$ & $1,415.32$ & $\sqrt{ }$ & $\sqrt{ }$ & $\sqrt{ }$ & $\sqrt{ }$ & $\mathrm{X}$ \\
\hline 4 & Japan & Nikkei & $24,083.51$ & $21,877.89$ & $\sqrt{ }$ & $\sqrt{ }$ & $\sqrt{ }$ & $\sqrt{ }$ & $\sqrt{ }$ \\
\hline 5 & Malaysia & KLCI & $1,588.88$ & $1,473.25$ & $\sqrt{ }$ & $\sqrt{ }$ & $\sqrt{ }$ & $\sqrt{ }$ & $\sqrt{ }$ \\
\hline 6 & Korea & KOSPI & $2,262.64$ & $2,029.60$ & $\sqrt{ }$ & $\sqrt{ }$ & $\sqrt{ }$ & $\sqrt{ }$ & $\sqrt{ }$ \\
\hline 7 & Saudi Arab & Tadawul & $8,469.71$ & $7,213.03$ & $\sqrt{ }$ & $\sqrt{ }$ & $\sqrt{ }$ & $\sqrt{ }$ & $\sqrt{ }$ \\
\hline 8 & UAE & ADI & $5,213.25$ & $4,141.61$ & $\sqrt{ }$ & $\sqrt{ }$ & $\sqrt{ }$ & $\sqrt{ }$ & $\sqrt{ }$ \\
\hline
\end{tabular}

Some of the studies have analyzed the impact of COVID-19 on stock return using event study and some of the studies have used panel data analysis. When the efficient market hypothesis is valid the influence of particular event might be reflected in the change of stock price to explain the effect of the information disclosure (Liu, Manzoor, wang, Zhang, \& Manzoor, 2020). However, a particular event or circumstances means something particular, for instance, dividend, change on government policy, political changes, or a particular event. The impact of pandemic infectious disease started on $31^{\text {st }}$ December 2019 and it is still ongoing, none of the 
research has been able to predict when this outbreak will stop. Liu, Manzoor, wang, Zhang, \& Manzoor (2020) have analyzed panel data for the verification of results of event study and stated that the findings were same. This is initial period. Hence, the findings may have been same. If it goes for long time the findings would be different. In such situation the analysis of panel data could be better than event study. So, this paper has employed the panel data analysis.

\section{Models}

The empirical work has been based on panel data. Regression can then capture both variation on cross-section data, and variation over time. Another advantage of using panel data is that it allows for heterogeneity. Furthermore, the number of observations available when testing the regression is greatly increased in a panel framework and this can substantially increase the explaining power of the determining variables (Pedroni,1999; Aergis, Filippidis \& Economidou, 2007). Similarly, Baltagi (2008); Gujarati (2012); Hsiao (2014) stated that the panel data regression reduces estimation bias and multi co-linearity, controls for individual heterogeneity, and identify the time varying relationship between explaining variables and explained variable.

Regression model: $(C S R)_{i t}=\beta 0+\beta 1(C C C)_{i t}+\beta 2(C D C)_{i t}+\varepsilon_{i t}$

Where, the CSR refers changes on stock return of stock $i$ at day t, CCC stands for changes on COVID-19 cases and CDC denotes changes on death from COVID-19, and $\varepsilon_{\mathrm{it}}$ represents error terms.

Further, the regression relationship has been examined at industry levels. The dependent variable has been considered stock return of specific industry and independent variables have been considered as before; changes in confirmed Civid-19 cases and changes in death from COVID-19.

Model (1): $(C S R-B F)_{i t}=\beta 0+\beta 1(C C C)_{i t}+\beta 2(C D C)_{i t}+\varepsilon_{\mathrm{it}}$

Model (2): $(C S R-I M)_{i t}=\beta 0+\beta 1(C C C)_{i t}+\beta 2(C D C)_{i t}+\varepsilon_{i t}$

Model (3): $(C S R-S U)_{i t}=\beta 0+\beta 1(C C C)_{i t}+\beta 2(C D C)_{i t}+\varepsilon_{i t}$

Model (4): $(C S R-I H C)_{i t}=\beta 0+\beta 1(C C C)_{i t}+\beta 2(C D C)_{i t}+\varepsilon_{i t}$ 
Model (5): $(C S R-T T)_{i t}=\beta 0+\beta 1(C C C)_{i t}+\beta 2(C D C)_{i t}+\varepsilon_{i t}$

Where, the $(C S R-B F)_{i t}$ refers change on stock return of stock $i$ at day $t$ of banking and finance industry, $(C S R-I M)_{\text {it }}$ denotes changes on stock return of stock $i$ at day $t$ of industry and manufacturing unit, $(C S R-S U)_{\text {it }}$ represents changes on stock return of stock $i$ at day $t$ of service and utility industry, $(C S R-I H C)_{\text {it }}$ stands for the changes on stock return of stock $i$ at day $t$ of insurance and health care industry, (CSR-TT) $)_{\text {it }}$ refers changes on stock return of stock $i$ at day $t$ of travel and tourism industry, CCC stands for changes on COVID-19 cases and CDC denotes changes on death from COVID-19, and $\varepsilon_{\text {it }}$ represents error terms.

Then the impact of categorical variables has been examined developing categorical dummies. To avoid the dummy variables, trap the common intercept has been eliminated. The categorical variables have been considered by size of stock market based on market capitalization - high, moderate and low. Similarly, the impact of geographical area - Pacific Asia and Middle East - and regulations government regulated, and autonomous BOD regulated - have been examined. Each category has been examined in separate model otherwise the model might face multi co-linearity problem if all categorical dummies placed in the same model.

\section{Regression models with categorical dummies}

Model-i:(CSR $)_{i t}=\alpha_{1}(P A \text { dummy })_{1 i}+\alpha_{2}(M E \text { dummy })_{2 i}+\beta_{1}(C C C)_{i t}+\beta_{2}(C D C)_{i t}+\varepsilon_{i t}$

Model-ii: $(C S R)_{i t}=\alpha_{1}$ (high dummy $)_{1 i}+\alpha_{2}$ (moderate dummy) ${ }_{2 i}+\alpha_{3}(\text { low dummy })_{3 i}$ $+\beta_{1}(C C C)_{i t}+\beta_{2}(C D C)_{i t}+\varepsilon_{\text {it }}$

Model-iii: $(C S R)_{i t}=\alpha_{1}(\text { GR dummy })_{1 i}+\alpha_{2}(B O D R \text { dummy })_{2 i}+\beta_{1}(C C C)_{i t}+\beta_{2}(C D C)_{i t}$ $+\varepsilon_{\text {it }}$

Model-iv: $(\text { CSR })_{i t}=\alpha_{1}(\text { China dummy })_{1 i}+\alpha_{2}$ (India dummy $)_{2 i}+\alpha_{3}(\text { Israel dummy })_{3 i}$

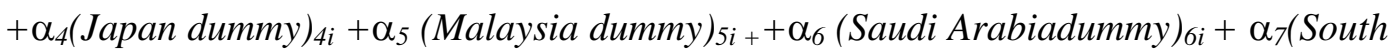
Koreadummy $)_{7 i}+\alpha_{8}(U A E \text { dummy })_{8 i}+\beta_{1}(C C C)_{i t}+\beta_{2}(C D C)_{i t}+\varepsilon_{\mathrm{it}}$

\section{Test of Granger causality}


At one extreme, people who believe that everything causes everything and at another extreme are people who deny the existence of the causation whatsoever. These days the economists are worried that what would the modality of economy after COVID-19. Various governments have been lunching economic packages. These events and concerns show that the pandemic has impact on economy including financial markets. Hence to what extent it has influenced the stock market, Granger Causality Test, has been employed for the examination of results, following is bivariate model.

$$
\begin{aligned}
& \mathrm{Y}_{\mathrm{t}}=\sum_{i=1}^{n} \alpha_{\mathrm{i}} X_{t-1}+\sum_{i=1}^{n} \beta_{\mathrm{j}} Y_{t-j}+\varepsilon_{1 \mathrm{t}} \\
& \mathrm{X}_{\mathrm{t}}=\sum_{i-1}^{n} \lambda_{\mathrm{i}} X_{t-i}+\sum_{i-1}^{n} \mathrm{~d}_{\mathrm{j}} Y_{t-j}+\varepsilon_{2 \mathrm{t}}
\end{aligned}
$$

\section{Limitations}

This study has assumed that the investors do react based on the information of the previous day, if the stock market is closed. So, while calculating the change on stock return the index price of previous day has been carried on the day of closure. Hence, there is no change on stock return on the day of stock market closure. The elimination or estimation of data with logical assumption has been practiced. In this study carrying the information of last day seems more meaningful. So the data have been added with the assumption. The study period started from $20^{\text {th }}$ January $2020\left(1^{\text {st }} \mathrm{WHO}\right.$ situational report) till May end. In the initial period some of the countries have been affected greatly and later other countries have been affected, whereas the impact of COVID-19 has not entirely been predicted. So, the findings of the study might be contextual. The changes of stock return can be both positive and negative, but the growth of cases and deaths are non-negative. Samples have been chosen considering specific assumptions. However, the analysis of the evidences would be able to estimate the effects of the pandemic on stock return. To some extent this study might be able to add a brick to carry further studies regarding the impact of COVID-19 on stock return.

\section{Results and Discussions}

Table 2: Summary statistics 


\begin{tabular}{|l|l|l|l|l|l|l|l|}
\hline Variable & Mean & Median & Minimum & Maximum & Std. Dev. & Skewness & Ex. Kurtosis \\
\hline CCC & 0.087 & 0.0108 & 0.000 & 4.40 & 0.2387 & 10.584 & 164.46 \\
\hline CDC & 0.057 & 0.0000 & 0.0000 & 4.00 & 0.2058 & 10.916 & 163.55 \\
\hline TotalCSR & -0.0011 & 0.0000 & -0.1315 & 0.089 & 0.01904 & -0.5700 & 7.2130 \\
\hline BF-CSR & -0.0017 & 0.0000 & -0.1681 & 0.112 & 0.0222 & -0.7984 & 9.2240 \\
\hline IM-CSR & -0.0016 & 0.0000 & -0.1742 & 0.160 & 0.0267 & -0.3475 & 7.9034 \\
\hline SU-CSR & -0.0007 & 0.0000 & -0.175 & 0.0867 & 0.0197 & -1.0152 & 10.941 \\
\hline IHC-CSR & 0.0005 & 0.0000 & -0.0921 & 0.0895 & 0.0199 & -0.0122 & 5.0782 \\
\hline TT-CSR & -0.0006 & 0.0000 & -0.155 & 0.368 & 0.0279 & 2.5169 & 41.337 \\
\hline
\end{tabular}

The changes on daily conformed cases and deaths from COVID-19 have been more deviated than stock return. That is due to rampant growth of the disease. Whereas, stock returns have also been changed but at normal rate. The maximum changes on confirmed cases have been observed 4.4 (440 percent), and 4 (400 percent) on changes on deaths. Maximum change observed in the stock return of manufacturing and industry 0.16 (16 percent) and minimum change observed in service and utility sector -0.175 (negative 17.5 percent).

Table 3: Correlation between variables

\begin{tabular}{lccc}
\hline CCC & CDC & Total SR & \\
\hline 1.0000 & & -0.0789 & CCC \\
\hline & 0.1480 & -0.0643 & CDC \\
\hline & 1.0000 & 1.0000 & Total \\
\hline
\end{tabular}

The above table shows the correlation between stock return, and COVID-19 cases and deaths. The correlation shows negative and low association between stock return and COVID-19 cases and death. The low correlation shows low association 
between variables. These evidences reduce the chances of having multi co-linearity between independent variables.

Figure 2: Panel plot of stock return

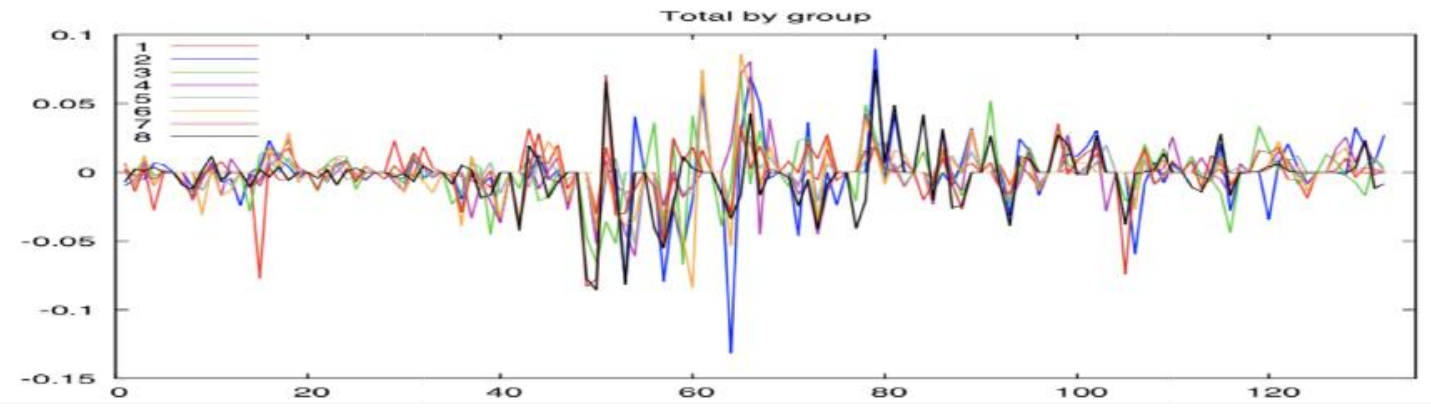

The panel plot of dependent variable stock return shows that it is less volatile in the initial and later period and more volatile in the period of March and April. This evidence shows that if this pandemic continued for longer period the stock markets would be affected, though it could be a platform for the investment too.

Figure 3: Normality of residuals

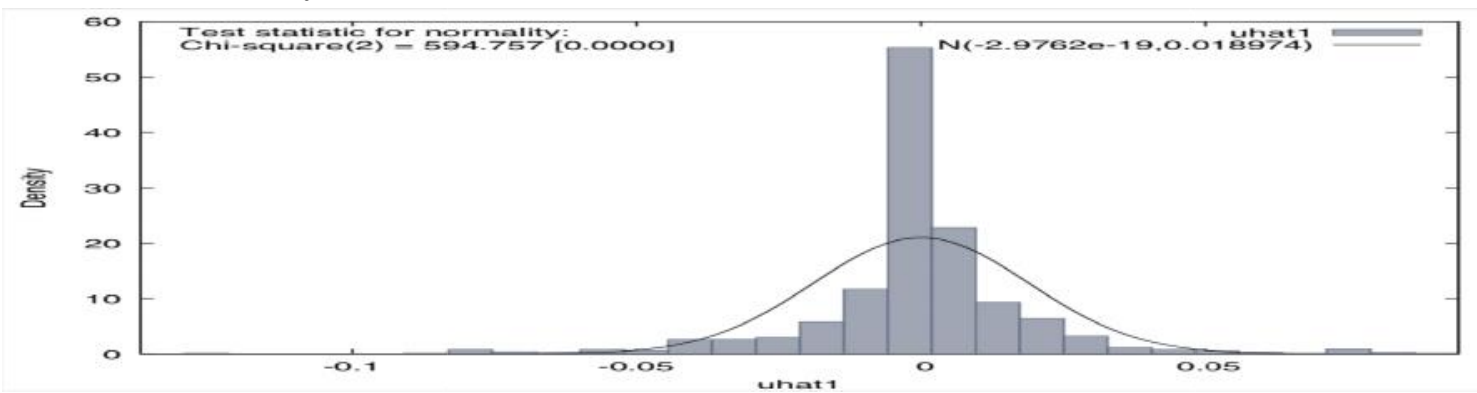

The data have been normally distributed except some outliers. In the initial period the growth of confirmed cases has been observed high. It depends on the testing boundaries also. As the government expand the testing boundaries the chances of getting new cases is high and vice-versa. So, it is rational of getting some outliers.

Table 4: Panel regression Panel-A: Regression results considering stock return as a dependent variable and changes on confirmed cases of COVID-19 and death form COVID-19 independent 
variables of overall stock markets as well as cross-over the industries using pooled

OLS.

\begin{tabular}{llll}
\hline Models & Constant & CCC & CDC \\
\hline Model:1 & -0.000355088 & -0.00565791 & -0.00497393 \\
(Overall) & $(0.5770)$ & $(0.0224 * *)$ & $(0.0832 *)$ \\
\hline Model:2 & -0.000780630 & -0.00784048 & -0.00427454 \\
Banking and Finance & $(0.2936)$ & $(0.0067 * *)$ & $(0.2021)$ \\
\hline Model:3 & -0.000856067 & -0.00826562 & -0.00144609 \\
Industry and Manufacturing & $(0.3395)$ & $(0.0178 * *)$ & $(0.7203)$ \\
\hline Model:4 & -0.000131547 & -0.00604797 & -0.000987669 \\
Services and Utilities & $(0.8426)$ & $(0.0190 * *)$ & $(0.7408)$ \\
\hline Model:5 & 0.00111358 & -0.00562845 & -0.00163052 \\
Insurance and Healthcare & $(0.0966 *)$ & $(0.0308 * *)$ & -0.00339828 \\
\hline Model:6 & $9.86647 \mathrm{e}-05$ & -0.00733128 & $(0.5482)$ \\
Transport and Tourism & $(0.9281)$ & $(0.1240)$ & $*$ refers \\
\hline Where, *** represents & significant at 1 percent level of significance, $* *$ rerent \\
significant at 5 percent level of significance, and $*$ denotes significant at 10 percent \\
level of significance.
\end{tabular}

As per my data the pooled OLS model is best fitted rather than fixed effect and random effect models using Hausman Test. The results show that the changes on daily cases have significant and negative relationship with stock return. This implies that as the infectious disease spread over (increased), the stock return has been decreased. The reasons could be investors' psychology regarding the impact of this disease on economy. If it is influenced severely in the economy, many jobs might be collapsed and income generating sources would be condensed and the investment activities would be curtailed by the investors. This would reduce the demand of stock and low demand low price and less stock return.

The impact of death from COVID-19 has been observed negative. This implies that as the death increased stock return would decrease. But it has been observed insignificant relationship; the reasons could be behind that the mortality rate from this disease has been found low (china: 5.49\%, India: 2.8\%, Japan: 5.27\%, Saudi Arabia: 0.56\%, Israel: 1.6\%, Korea Republic: 2.3\%, UAE: 0.78\%, Malaysia: $1.48 \%$ ) up to the end of May 2020 (worldometers: https://www.worldometers.info/world-population/). Further, the patients who have 
been infected from corona virus would have uncertain time gap between infection and death. Therefore, the investors show their reactions at the time of infections than on death.

From this it can be inferred that the people of middle economic class would be more influenced than low and high. Because, lower economic class people were already struggling for their basic needs and in the period of pandemic disease it could be more severe. Whereas, the government support and support from different institutions and people may help for their survival. After this pandemic they will struggle for basic needs again. The upper-class people could hold their savings in the period of this pandemic. As all the nations have been providing treatment at free of cost. After this pandemic disease, the fund can be utilized to gain more from low investment. So, these people will gain previous economic condition soon. But the middle-income people might fall into low income people and there might be larger economic gap between rich and poor.

Before conducting this study, it was expected that the pharmaceutical industries, health, and care industries would have positive impact and the tourism and transport industry would have more severe impact of this disease. The results did not support that presumed hypothesis. All the industry-wise relationship between stock return and daily cases/ deaths has been observed negative. The reason could be the investor's psychology of fear. So, from the analysis of data from $20^{\text {th }}$ January to end of May 2020 it can be said that, there has been no significant differences in the relationship between stock return and changes on daily cases and deaths from this disease at cross-over industry level.

Liu, Manzoor, wang, Zhang, \& Manzoor (2020); Al-Awadhi, Alsaifi, AlAwadhi \&Alhammadi (2020) have argued that COVID-19 has significant and negative impact on stock return. Similarly, the uncertainty in the economy makes volatile in the stock market (Bowes, 2018). Whereas, the findings have been contradicted with Sansa (2020), there has been significant and positive relationship between stock return and COVID-19 outbreaks. But the findings regarding the relationship between stock return and changes on daily death rate have produced contrasting results. The earlier studies have found significant relationship, but this study has concluded insignificant relationship. 
Panel-B: Regression results considering stock return as a dependent variable and confirmed cases of COVID-19 and death form COVID-19 independent variables with economic size dummies, geographical region dummies, and regulation dummies.

\begin{tabular}{|c|c|c|c|}
\hline Models and variables & Coefficients & t-values & P-value \\
\hline \multicolumn{4}{|c|}{ Modle:1 (geographical dummies) } \\
\hline $\mathrm{CCC}$ & -0.00561195 & $(-2.267)$ & $0.0236 * *$ \\
\hline CDC & -0.00501113 & $(-1.746)$ & $0.0810 *$ \\
\hline Pacific Asia & $5.88716 \mathrm{e}-05$ & $(0.07547)$ & 0.9399 \\
\hline Middle East & -0.00104902 & $(-1.062)$ & 0.2887 \\
\hline \multicolumn{4}{|c|}{ Modle:2 (Economic size dummies) } \\
\hline $\mathrm{CCC}$ & -0.00566519 & $(-2.285)$ & $0.0225 * *$ \\
\hline $\mathrm{CDC}$ & -0.00500612 & $(-1.744)$ & $0.0815^{*}$ \\
\hline High & 0.000200524 & $(0.1683)$ & 0.8664 \\
\hline Moderate & $-8.99077 \mathrm{e}-05$ & $(-0.1032)$ & 0.9178 \\
\hline Low & -0.00143010 & $(-1.200)$ & 0.2306 \\
\hline \multicolumn{4}{|l|}{ Modle:3 (Regulation dummies) } \\
\hline $\mathrm{CCC}$ & -0.00562696 & $(-2.273)$ & $0.0233 * *$ \\
\hline CDC & -0.00495255 & $(-1.726)$ & $0.0847 *$ \\
\hline Government regulated & 0.000149050 & $(0.1254)$ & 0.9003 \\
\hline Autonomous BOD regulated & -0.000528614 & $(-0.7297)$ & 0.4658 \\
\hline \multicolumn{4}{|l|}{ Modle:4 (Countries dummies) } \\
\hline $\mathrm{CCC}$ & -0.00564906 & $(-2.270)$ & $0.0234 * *$ \\
\hline $\mathrm{CDC}$ & -0.00505392 & $(-1.755)$ & $0.0795 *$ \\
\hline China & 0.000163446 & $(0.09789)$ & 0.9220 \\
\hline India & -0.000362581 & $(-0.2145)$ & 0.8302 \\
\hline Israel & -0.000382983 & $(-0.2284)$ & 0.8194 \\
\hline Japan & 0.000241386 & $(0.1442)$ & 0.8854 \\
\hline Malaysia & $7.04181 \mathrm{e}-05$ & $(0.04225)$ & 0.9663 \\
\hline Saudi Arabia & 0.000211161 & $(0.1256)$ & 0.9001 \\
\hline South Korea & -0.000272022 & $(-0.1616)$ & 0.8717 \\
\hline UAE & -0.00247464 & $(-1.483)$ & 0.1385 \\
\hline
\end{tabular}

The categorical variables have shown insignificant effect on the relationship between stock return and confirmed daily cases of COVID-19 and deaths. All the categorical variables; stock market size in terms of market capitalization, geographical area, regulation and country have no impact at all on the relationship

Full text of this article can be downloaded from www.craiaj.com and www.nepjol.info 
between stock return and COVID-19 epidemic disease. As the presumed hypothesis was that the cultural, rituals and immunity power of the different people of different place and countries are different and the impact of COVID-19 in different nation would be different. As such the impact on stock markets would be different at different place and countries. Similarly, the presumed hypothesis was that the different regulating institutions and economic size of stock markets would have significant impact. These all presumed hypothesis have invalidated. This is true the impact of COVID-19 is different as per different nations and places. But all the stock markets have been severely influenced by this pandemic. From this it can be inferred that the event of any nations or places would influence the stock market worldwide. The findings are in line with Bowes (2018), the uncertainty in the economy makes volatile in the stock markets.

Table 5: Causal relationship

\begin{tabular}{|c|c|c|}
\hline \multirow[t]{2}{*}{ Clusters / Industries / Countries } & \multicolumn{2}{|l|}{ Causal relationship } \\
\hline & $\mathrm{CCC}$ and stock return & CDC and stock return \\
\hline Overall stock markets & $\rightarrow$ & $\leftarrow$ \\
\hline Banking and finance & $\rightarrow$ & $\leftarrow$ \\
\hline Industry and manufacturing & $\leftrightarrow$ & $\leftarrow$ \\
\hline Services and utilities & $\rightarrow$ & $\leftarrow$ \\
\hline Insurance and healthcare & $\rightarrow$ & $\leftrightarrow$ \\
\hline Transportation and tourism & $\leftrightarrow$ & 0 \\
\hline Asia pacific & 0 & 0 \\
\hline Middle east & $\leftrightarrow$ & $\leftrightarrow$ \\
\hline Large stock markets & 0 & 0 \\
\hline Moderate stock markets & $\rightarrow$ & 0 \\
\hline Small stock markets & $\leftrightarrow$ & $\leftarrow$ \\
\hline Government regulated & $\rightarrow$ & $\leftrightarrow$ \\
\hline Autonomous BOD regulated & 0 & $\leftarrow$ \\
\hline China & 0 & 0 \\
\hline India & 0 & 0 \\
\hline Israel & 0 & $\leftarrow$ \\
\hline Japan & 0 & 0 \\
\hline Malaysia & 0 & $\leftrightarrow$ \\
\hline Saudi Arabia & $\rightarrow$ & 0 \\
\hline South Korea & 0 & 0 \\
\hline UAE & $\rightarrow$ & 0 \\
\hline
\end{tabular}

Full text of this article can be downloaded from www.craiaj.com and www.nepjol.info 
The symbol $\leftrightarrow$ refers bidirectional causal relationship, $\rightarrow$ or $\leftarrow(\rightarrow$ first variable causes latter variable and $\leftarrow$ latter variable causes first variable) denotes unidirectional causal relationship, 0 stands for no causal relationship.

Considering the data of eight nations; China, India, Israel, Japan, Korea Republic, Malaysia, Saudi Arabia, and United Arab Emirates in overall the changes on daily cases of COVID-19 has been predictable regarding the stock return. Similarly, considering industry specific results in each industry- banking and finance, industry and manufacturing, services and utility, insurance and health care, and transport and tourism - shows daily growth of confirmed cases have explaining power regarding the stock return. But the daily death rate has no explaining power in overall as well as all industries, except insurance and health care. The changes on death rate have explained the stock return of insurance and health care industry. It could be due to the relatedness of insurance and death. Hence it has held the explaining power in this particular industry. Otherwise, the change in death rate has no explaining power regarding the stock return. Similarly, the changes on daily cases have been holding the predicting power (moderate stock markets, low stock markets, government regulated) in the context of Middle East, Saudi Arabia and UAE, except these there is no predicting power in other countries and clusters. Regarding the predictability of changes in death rate about the stock return in the context of Middle East, government regulated, and Malaysia have shown significant relationship, except these all the countries, economic groups, regulations, and geographical groups have been observed insignificant predicting power.

\section{Conclusion}

In nutshell, the study has been conducted using causal comparative research design. The major tools for analysis, regression analysis and Granger Causality Test have been employed. The study has covered 132 days from $20^{\text {th }}$ January to $30^{\text {th }}$ May 2020. Sample countries consisted eight nations; China, India, Israel, Japan, Korea Republic, Malaysia, Saudi Arabia, and United Arab Emirates. The relationship between stock return and changes on daily confirmed cases and deaths from this disease has been examined. Further, the impact of categorical variables, economic size based on market capitalization - high moderate and low; geographical area- Pacific Asia and Middle East; and regulation - government regulated, and autonomous board of directors regulated variables - have been examined with the help of categorical dummies. Based on the analysis it was concluded that impact of COVID-19 on stock 
return revealed that the changes on daily confirmed new cases have severely inflected stock returns in overall as well as cross-over the industries. Whereas, the influence of death form COVID-19 has been found negative but mostly insignificant. The categorical variables size of economy, geographical area, regulations, and countryspecific along with new cases and daily deaths impacts have been found very low. The findings have been in line with the study of Liu, Manzoor, wang, Zhang, \& Manzoor ( 2020); Al-Awadhi, Alsaifi, Al-Awadhi \&Alhammadi (2020); Bowes (2018). However, the findings have contradicted with the findings of Sansa (2020). Based on the findings it can be inferred that the economic gap would be increased after this pandemic disease. Similarly, the reduction of middle-class investors in stock markets would increase the chance of control in limited hands. In this regards the future research avenues could be impact of COVID-19 on overall economy and living standard of people. Moreover, the impact of COVID-19 on employment and the role of government can also be interesting area for the future study. After this pandemic what will be the role of government? Does the efficient market hypothesis will exist, or the modality of economy will be changed? For these studies the findings of claustral variables could be landmark.

\section{References}

Aergis, N., Filippidis, I. \& Economidou, C. (2007). Financial deepening and economic growth linkages: A panel data analysis. Review of World Economics, (143), pp. 179-198.

Al-Awadhi, A., Alsaifi, K., Al-Awadhi, A. \&Alhammadi, S. (2020). Death and contagious infectious disease: Impact of the COVID-19 virus on stock market returns. Journal of Behavioral and Experimental Finance, (27), pp. 1-5.

Baltagi, B. (2008). Econometric analysis of panel data. John Wiley and Sons.

Banz, R.W. (1981). The relationship between returns and market value of common stocks. Journal of Financial Economics, Vol. 9 (1), pp. 3-18.

Chang, K.C., Hamao, Y. \& Lakonishok, J. (1991). Fundamentals of stock return in Japan, Journal of Finance. Vol. 46, pp. 1739-1764.

David, B. (2018). Stock market volatility and presidential election uncertainty: Evidence from political future market. Journal of Applied Business Research, United States: Southeastern Louisiana University, (34), pp. 143-150 
Fama, E. F. (1998). Market efficiency, long-term returns, and behavioral finance. Journal of Financial economics, United States: Chicago. (49), pp. 283-306.

Fama, E. F. \& French, K. R. (2011). Size value and momentum in international stock returns. working paper, DOI: http://ssm.com/abstract $=1720139$.

Gujarati, D., Porter, D. \&Gunasekar, S. (2012) Basic econometrics. Mc Graw Hill: New Delhi.

Hsiao, C. (2014). Analysis of panel data. Cambridge University Press.

Kiem, D. B. (2018). Size related anomalies and stock return seasonality. Journal of Financial Economics, Vol. 12 pp. 13-32.

Liu, H., Manzoor, A., wang, C., Zhang, L \& Manzoor, Z. (2020). The COVID-19 outbreak and affected countries stock markets response. International Journal of Environmental Research and Public Health, (17), pp. 1-19. Doi: https://doi.org/10.3390/ijerph17082800

Malkiel, B. G. (2003). The efficient market hypothesis and its critics. Journal of Economic Perspectives, (17), pp. 59-82.

Mallikarjunappa, T. (2004). How do the Indian stock prices react to quarterly earnings? ICFAI Journal of Applied Finance, (10), pp. 37-48.

Mallikarjunappa, T. \& Dsouza, J. (2013). A Study of semi-strong form of market efficiency of Indian stock market. Amity Global Business Review, (8), pp. 6068.

Onali, E. (2020). COVID-19 and stock market volatility. Available on $12^{\text {th }}$ June, 2020: https://www.researchgate.net/publication/340609711_COVID19_and_stock_market_volatility/citation/download.

Pedroni, P. (1999). Capital values for cointegration test in heterogeneous panels with multiple regression. Oxford Bulletin of Economics and Statistics, (Special Issue), pp. 653-670.

Sansa, N. (2020). The impact of the COVID-19 on the financial markets: Evidence from China and USA. Journal of Social Science and Humanities. (2), pp. 2939. 